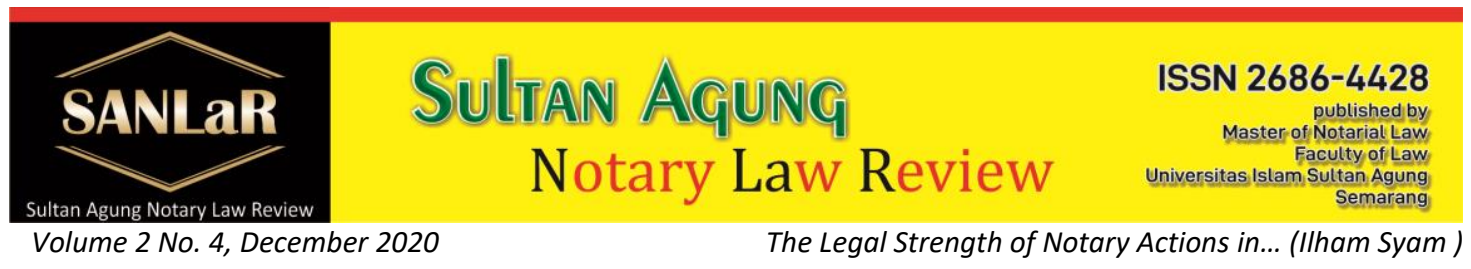

\title{
The Legal Strength of Notary Actions in the Implementation of Parate Execution towards Responsibility \& Execution Rights to Fidusian Objects
}

\author{
Ilham Syam ${ }^{*}$, Amin Purnawan ${ }^{* *}$ and Akhmad Khisni $\left.{ }^{* * *}\right)$ \\ *) Students of Master of Notary Law, Faculty of Law, Universitas Islam Sultan \\ Agung (UNISSULA) Semarang, E-mail: ilhamsyam1212@gmail.com \\ $\left.{ }^{* *}\right)$ Lecturer of Master of Notary Law, Faculty of Law, Universitas Islam Sultan \\ Agung (UNISSULA) Semarang \\ $\left.{ }^{* *}\right)$ Lecturer of Master of Notary Law, Faculty of Law, Universitas Islam Sultan \\ Agung (UNISSULA) Semarang
}

\begin{abstract}
This research aims to: to find out howthe legal force of the notary deed in the application of the execution parate of the right of collateral and the parate of execution of the fiduciary object. The approach method in this research is empirical normative, the data source is obtained from the literature and the legal materials used are primary, secondary and tertiary legal materials which are then analyzed by means of qualitative analysis. Based on the results of data analysis, it can be concluded that the material rights fiduciary provides guarantees. The collateral object is tangible, intangible and immovable movable object which cannot be guaranteed with a mortgage. Fiduciary security is widely used by financing companies. The debtor in default, the leasing party executes the fiduciary object unilaterally, this is considered contrary to the 1945 Constitution. Article 15 paragraph (2) and Article 15 paragraph (3) Law No. 42 of 1999 concerning Fiduciary Guarantee is subject to a judicial review. Formulation of the problem, how the execution of fiduciary guarantees after the decision of the Constitutional Court No. 18 / PUU- XVII / 2019. Research method, using library research in the form of secondary data. This research is juridical normative and qualitative research type. The discussion after the decision of the Constitutional Court No. 18 / PUUXVII / 2019 states that Article 15 paragraph (2) and Article 15 paragraph (3) of Act No. 42 of 1999 are contrary to the 1945 Constitution. Conclusion, before the Constitutional Court decision the execution of the object of fiduciary guarantee based on Article 29 of the Act No. 42 of 1999 concerning Fiduciary Guarantee. After the Decision of the Constitutional Court No. 18 / PUU-XVII / 2019 states that the collateral execution cannot be carried out unilaterally by the creditor, but must go through a decision of the District Court, unless there is an agreement regarding the default between the debtor and the creditor and the debtor voluntarily submits the object of fiduciary collateral.
\end{abstract}

Keywords: Parate Execution; Mortgage Law; Mortgage right; Fiduciary; Default. 


\section{Introduction}

Economic Recovery as a result of the economic process that hit Indonesia requires strong legal instruments, including one of which is the law of guarantee. Guarantee law is always related to economic law, because banking in the economic sector, especially in the industrial, trade, corporate, transportation and other sectors, requires funds. As we know, banking, especially lending, has a very high degree of risk. Therefore, in channeling credit, banks must adhere to the principle of prudence and always pay attention to the principle of sound credit, considering that the funds channeled by banks come from people who entrust their money to the bank.

In principle, the disbursement of credit by banks does not always have to be accompanied by collateral requirements, because collateral is considered to exist with the opportunity and prospects for bright business prospects from prospective borrowers. The expansion of credit that is expansive on the one hand is of course very beneficial for the community because they will be able to easily obtain funds (in the form of credit or bank loans) without having to be accompanied by complicated and troublesome conditions. On the other hand, the expansion of lending or bank loans opens up opportunities for credit congestion, the bank has carried out a careful assessment of its customers.

Lending without collateral credit increases the risk of loss faced by the bank. Banks must carry out balancing of interest, which must be able to integrate profitability orientation with capturing all business opportunities, but also strive for safety to be distributed to customers. Without taking these steps, the occurrence of problems loan that leads to credit congestion is just a matter of time.

With the guarantee (collateral), when the debtor (credit recipient) breaks his promise (wanprestasi), the creditor gets reimbursed from the sale (auction) of the collateral. In addition, especially for banking institutions, it is common practice that in lending, banks must take collateral as collateral for repaying the credit. In addition, banks must pay attention to legal aspects of security (legal security).

The types of guarantee institutions known in banking practice (principal guarantees and additional guarantees) have similarities and similarities to the existing division of guarantee institutions as determined by legal experts. Sri Soedewi Maschoen Sofwan classifies guarantee institutions into four groups:

a. Guarantees that are born because they are determined by law and guarantees that are born because they are promised, which are often referred to as general guarantees and special guarantees;

b. Guarantee that is material and personal guarantees;

c. Collateral for immovable objects and collateral for movable objects;

d. Guarantee by controlling the object and guarantee without controlling the object. 
Therefore, in every provision of funds made by banks in terms of providing loans to debtors, by providing legal force to these creditors.

\section{Research Methods}

The approach method in this research is empirical normative, the data source is obtained from the literature and the legal materials used are primary, secondary and tertiary legal materials which are then analyzed by means of qualitative analysis.

\section{Results and Discussion}

3.1. The Legal Strength of Notary Activities In The Implementation of Parate Execution to Liability Rights

How is the Legal Power of Notary Deed in the Implementation of Execution Parate of Mortgage Rights:

The understanding of parate of execution given by the doctrine, the authority to sell on one's own power or parate of execution, means that if the debtor is in default, the creditor can carry out the execution of the object of guarantee, without having to ask for fiat from the Chairman of the Court, without having to follow the rules of the game in the Law of Procedure, for that there are rules of the game itself. There is no need for confiscation in advance, no need to involve bailiffs and therefore the procedure is easier and costs easier.

It was also explained in the opinion of Sri Soedewi Mascjhoen Sofwan, that the right to sell or power alone uses two things, namely:

a. No executorial title is required in exercising its rights / execution.

b. Can carry out the execution directly (independently) regardless of the bankruptcy of the debtor (outside the court) because he is classified as a separatist.

Act No. 4/1996 concerning Mortgage Rights on Land and Land-Related Objects (UUHT) is deemed capable of accommodating the interests of banks as creditors to secure credit and guarantee debt repayment from debtors, so that this is expected to create conditions. Which is conducive, the laws and regulations previously contained in Articles 1131 and 1132 of the Book

Civil law laws that determine all debtor assets, both existing and existing, serve as collateral for all agreements with creditors, which do not provide a sense of security to creditors.

3.2. The Legal Strength of Notary Actions in the Implementation of Execution Parate in Fidusian Objects

Execution of fiduciary guarantees prior to the decision of the Constitutional Court, is carried out if the debtor or fiduciary makes a breach of promise or 
defaults. The debtor in a state of default or default means that the debtor is unable to fulfill the obligations as stipulated in the engagement or agreement. Failure to fulfill their obligations due to two things, first because of the debtor's fault, whether intentional or negligent, secondly due to compulsion (Overmacht / Forcemajeur). There are four conditions of default, namely not meeting achievement, late meeting achievement, fulfilling achievement illegally; do something that is according to the agreement is not valid. In an agreement, the debtor is deemed in default if the time limit specified in the agreement has passed. However, according to Article 1238 of the Civil Code, it still requires a written warning from the court (subpoena) and it can be said that the debtor is in default. Article 1238 of the Civil Code is no longer valid by the Supreme Court Circular Number 3 / 1963. According to Subekti, it is sufficient to be reprimanded personally or verbally by the creditor so that the debtor performs his achievements. In practice, there are cases of financial institutions (leasing) in running their business if the debtor is in default, the leasing company does not give verbal or written warnings as is the opinion of Subekti, but the company immediately executes without any summons using deb, collector services. The leasing company that hires the service of a debt collector carries out the execution of the collateral object by forcibly pulling the vehicle unilaterally leading to a criminal act. Based on Article 11 of Act No. 42 of 1999 concerning Fiduciary Security, objects used as fiduciary security are required to be registered at the fiduciary registration office at the office of the Ministry of Law and Human Rights. Application for registration is made by a fiduciary recipient (Article 13 paragraph (1). After registration, the fiduciary registration office issues a certificate of fiduciary security which is the same as the date of receipt of the fiduciary application (Article 14 of Act No. 42 of 1999 concerning Fiduciary Security. the words "For Justice Based on the One Godhead" (Article 15 paragraph 1). A fiduciary guarantee certificate has the same executorial power as a court decision which has permanent legal force (Article 15 paragraph 2). Based on Article 15 paragraph (1), if the fiduciary recipient does not register the fiduciary registration guarantee at the fiduciary registration office, the fiduciary guarantee has no executorial power and cannot be executed by force through the court if the debtor defaults. So, fiduciary registration serves to protect the creditor's interest as a fiduciary recipient. If the debtor who grants fiduciary defaults, the creditor can forcibly execute the object of fiduciary security. Furthermore, Article 15 paragraph (3) states if the debtor is in default, the recipient of fiduciary has the right to sell objects which are the object of Fiduciary security in his own power. Pursuant to Article 15 paragraph (3), the fiduciary recipient can parate the execution by unilaterally selling the object of the fiduciary security without compromising with the debtor who is in default. This is also contrary to Subekti's opinion which states that before the debtor is said to have defaulted, the creditor must first give a warning either verbally or in writing. Article 15 paragraph (2) and paragraph (3) of Act No. 42 of 1999 
concerning Fiduciary Security only protects the interests of creditors but does not protect the interests of debtors. In practice, financing institutions are still encountered in carrying out their business activities if the debtor is in default, there is no subpoena so that the debtor performs his performance, but immediately executes it using the services of a debtor collector. So based on the above description, it can be concluded that the debtor who gives the fiduciary is said to be in a state of injury if the debtor who gives the fiduciary does not fulfill his performance as agreed. The fiduciary performs the execution of the fiduciary guarantee object if the debtor who gives the fiduciary has committed a breach of promise or default. The executorial power on a fiduciary certificate has the same executive power as a judge's decision which is permanent and creditors can carry out unilateral forced execution (parate execution). This will certainly be detrimental to the debtor providing the fiduciary. Prior to the enactment of the Constitutional Court Decision Number 18 / PUU-XVII / 2019, the execution of the fiduciary guarantee is regulated based on Article 29 paragraph (1) which states that the execution of the fiduciary guarantee can be carried out by:

1. The implementation of the executorial title, on the fiduciary certificate there is the words "For Justice Based on One Godhead" has the same executorial power as a court decision which has permanent legal force.

2. The fiduciary recipient or creditor can sell the object which is the collateral for the fiduciary recipient through a public auction and collect the receivables from the proceeds of the sale.

\section{Closing}

\subsection{Conclusion}

The regulation regarding this Execution Parate in the Mortgage Rights Law aims to provide convenience to the bank as the creditor in executing the object of the guarantee right in order to get full repayment of the debt if the Debtor is in default. It's just that the convenience provided by the Mortgage Rights Law in fact cannot be utilized because there is confusion regarding the parate of execution in the Mortgage Rights Law, in the General Explanation number 9 of Act No. 4 of 1996 concerning Land Mortgage Rights (UUHT), in the general explanation of point 9, it is clear that the execution of the Execution Parate is based on Article 224 HIR.

Another result is the conflict of norms between Article 6 of Act No. 4 of 1996 concerning Mortgage Rights to Land and Land-Related Objects that have contradicted the provisions of Article $224 \mathrm{HIR}$, in judicial practice there is still dualism of opinion among judges on execution. Mortgage rights, judges who are given the freedom to decide disputes for the Execution Parate according to their beliefs, there are judges who think that the execution of the Execution Parate still has to ask for permission / fiat from the District Court but there are also 
judges who have a different opinion that the execution of the Execution Parate is no longer necessary to ask for permission / fiat from the court so that there is no legal certainty

Therefore it can be understood that the purpose of establishing the UUHT is to form an execution parate institution, in addition to providing advice that is deliberately made for creditors who hold the first Mortgage to get back their receivables in an easy and cheap way, with the intention of breaking through the formalities of procedural law, on the one hand the goal the establishment of an execution parate by law (ex lege), with the aim of strengthening the position of the creditors of the first Mortgage holder and the parties who get rights from it. Not yet Constitutional Court Decision No. 18 / PUU-XVII / 2019 the execution of the fiduciary guarantee in effect Article 29 can be done in several ways; a. the executorial title on the fiduciary certificate "For Justice Based on One Godhead" has the same executorial power as a court decision which has permanent legal force; The recipient of the fiduciary may sell the object which is the guarantee of the object of guarantee for the authority of the fiduciary through a public auction and collect the receivables from the sale proceeds; Underhand sales made based on the agreement between the giver and recipient of fiduciary with the highest price that is favorable to the parties. After the Constitutional Court Decision No. 18 / PUU-XVII / 2019 execution of fiduciary guarantees, states that Article 15 paragraph (2) the phrase "executorial power" and a court decision having legal force remain contrary to the 1945 Constitution. Creditors who receive fiduciary cannot carry out unilateral execution of the object of fiduciary security, but must submit a request for execution to the District Court. The phrase "breach of promise" contained in Article 15 paragraph (3) of the Fiduciary Guarantee Law, contradicts the 1945 Constitution and does not have binding legal force. The creditor cannot execute the guarantee of the fiduciary object unilaterally, unless it has been agreed between the creditor and the debtor in default and the debtor is willing to voluntarily submit the object of the guarantee.

\subsection{Suggestion}

1. To anticipate the prevailing laws and regulations and to ensure the smooth execution process, banks need to complete their credit documents with a statement from the debtor regarding (1) the status of land rights that will be used as credit collateral; and (2) approval to sell the collateral object either by auction or under hand if it is in default.

2. To avoid arbitrary actions by the creditor or fiduciary from executing the object of collateral in the event that the provider of the fiduciary breaches, the creditor should make subpoena up to three times to the invalid debtor. If the debtor does not heed the summons, then the creditor can parate 
execution on condition that based on the agreement of the parties to sell the collateral object through a public auction with the highest beneficial assets to both parties. If the parate attempt is unsuccessful, the last resort for execution is to file a request for execution through the District Court.

\section{References}

Books:

[1] Achmad Ali. (2004). Sosiologi Hukum, Kajian Empiris Terhadap Pengadilan. BP IBLAM, Jakarta, p. 19

[2] Burhan Bungin. (2008). Penelitian Kualitatif (Komunikasi, Ekonomi, Kebijakan Publik, Dan IImu Sosial Lainnya), edisi 1, cet.2: Kencana Prenadamedia Group, Jakarta.

[3] Cst Kansil, Christine S.t Kansil,Engelien R, palandeng dan Godlieb N mamahit, Kamus Istilah Hukum, (jakarta,JALA PERMATA AKSARA,2009)

[4] Soetadyo Wignjosoebroto. (1994). dari Hukum Kolonial ke Hukum Nasional, Dinamika Sosial Politik dalam Perkembangan Hukum di Indonesia, Raja Grafindo Persada, Jakarta.

[5] L.J van Apeldoorn dalam Shidarta, Moralitas Profesi Hukum Suatu Tawaran Kerangka Berfikir, (Bandung PT REVIKA ADITAMA,2006)

[6] Mertokusumo S.H., Prof. Dr, Sudikno, (2002) Hukum Acara Perdata Indonesia. Yogyakarta: Liberty Yogyakarta

[7] M. Yahya harahap, Pembahasan Permasalahan Dan Penerapan KUHP Penyidikan dan Penuntutan,(Jakarta, Sinar Grfika, 2002)

[8] Muhammad Nazir. (1988). Metode Penelitian, Gp.ia Indonesia, Jakarta

[9] Peter Mahmud Marzuki, 2010, Penelitian Hukum, Kencana, Jakarta

[10] Philipus M. Hadjon. (1987). Perlindungan Hukum Bagi Rakyat di Indonesia. Bina IImu, Surabaya

[11] Robert K. Yin, 2008, dalam bukunya yang berjudul Studi Kasus, Desain \& Metode, Edisi 1, cet 12, Raja Grafindo Persada, Jakarta

[12] Satjipto Rahardjo. (2006). Hukum Dalam Jagat Ketertiban, Jakarta: UKI Press

[13] Satijipto Raharjo. (2000). Ilmu Hukum,. Citra Aditya Bakti, Bandung 
[14] Soejono Soekamto dan Sri Mamudi. (1995). Penelitian Hukum Normatif Suatu Tinjauan Singkat, Jakarta, PT.Raja Grafindo Persada

[15] Soerjono Soekamto. (1986). Pengantar Penelitian Hukum, Jakarta, UI Press

[16] Shidarta. (2006). Moralitas Profesi Hukum Suatu Tawaran Kerangka Berfikir. Bandung: PT REVIKA ADITAMA

[17] Sudikno Mertokusumo in H. Salim Hs. (2010). Perkembangan Teori Dalam IImu Hukum. Jakarta: PT RAJAGRAFINDO PERSADA

[18] Sudikno Mertokusumo. (1991). Mengenal Hukum (Suatu Pengantar), Liberty, Yogyakarta

[19] Sumadi Suryabrata. (1998). Metodologi Penelitian, Jakarta, Raja Gofindo

[20] W.J.S. Poerwadarminta. (1986). Kamus Umum Bahasa Indonesia, Cet. IX, Balai Pustaka, Jakarta

Internet:

[1] https://notarisarief.wordpress.com/2011/04/21/pembuktian-aktaotentik/.html accessed on 23 September 2019, at 3:20 a.m. WITA

[2] http:///ppmunissula.com/jurnal.unissula.ac.id/index.php/akta/article/2547/1908 Regulation:

[1] Constitution of 1945 Republic of Indonesia

[2] Civil Code / BW (Burgerlijke wetboek)

[3] Code of Civil law

[4] Mortgage Laws 224 (HIR) and 258 (RBG) General Points Number 9

[5] Mortgage Law Articles 14 and 26 